Investigación

\title{
WORKLOAD IN NURSING: A CONCEPT ANALYSIS
}

\section{TRABAJAR EN LA ENFERMERÍA: UN ANÁLISIS DE CONCEPTO}

\section{Jaylien Diaz}

APRN, MSN, RN-BC, DNP Student, School of Nursing, Miami Regional College

\section{Karen Danvers-Perez}

DNP, MSN Ed., RN-BC, Assistant Professor, School of Nursing, Miami Regional College

$\overline{\text { Artículo recibido el } 19 \text { de octubre de 2018. Aceptado en versión corregida el } 7 \text { de diciembre }}$ de 2018.

\begin{abstract}
The process of assigning workload to nurses is significant in promoting high nursing retention rates, and positive patient outcomes. The concept, workload is widely used but there is no clear delineation of the concept as it relates to nursing. The aim of this analysis was to explore the concept of workload, as it relates to nursing using the Walker and Avant method. The analysis revealed: a) three attributes (time, mental state, and assignment); b) four antecedents (health, environment, nursing, and person); c) and three consequences (safety of practice, retention rate and cost). It is essential that nursing leaders create and use a systematic approach to guide the staffing process to create a balance workload. As a result, nursing practice will be safer and optimal patient outcomes will be achieved.
\end{abstract}

Key words: workload, work, load, nursing, concept analysis.

\section{RESUMEN}

El proceso de asignación de responsabilidad de trabajo a las enfermeras es importante en la promoción de retención de enfermeras y resultados positivos de los pacientes. El concepto de asignación de trabajo es ampliamente utilizado pero no hay ninguna medida especifica del concepto a lo que se refiere al oficio de la enfermera. El objetivo de este análisis fue explorar el concepto de asignación de trabajo, a lo que se refiere a enfermería, utilizando el método de Walker y Avant. El análisis reveló a) tres atributos (hora, estado mental y asignación), antecedentes b) cuatro (salud, entorno, enfermería y persona), c) y tres consecuencias (seguridad de la práctica, la tasa de retención y el costo). Es fundamental que líderes de enfermería crean y utilizan un enfoque sistemático para guiar el proceso de asignación de personal para crear una carga de trabajo equilibrada. Como resultado, será más segura la práctica de enfermería y se mejorarán los resultados de los pacientes.

Palabras claves: carga de trabajo, trabajo, carga, enfermería, análisis de concepto.

Correspondencia e-mail: jdiaz3214@my.mru.edu 


\section{INTRODUCTION}

Concepts are used to build theories, however, sometimes concepts are ambiguous and challenging to operationalize $^{1}$. To deeply examine a concept, a structural and a systematic approach is needed. The Walker and Avant's ${ }^{2}$ method is a systematic approach that can be employed when conducting a concept analysis. Walker and Avant's ${ }^{2}$ approach is widely used in nursing and will be used in this analysis to analyze the basic element of the concept, workload. The concept workload can be traced back to $1932^{3}$. Currently, the concept is being used by many professions but there is no clear delineation of the concept as it relates to nursing.

\section{Aim of the analysis}

The aim of this analysis is to explore the concept workload as it relates to the nursing profession. Walker and Avant format was used to conduct the analysis. Walker and Avant ${ }^{2}$ has an eight step process: (1) select a concept, (2) determine the aims of the analysis, (3) identify the uses of the concept, (4) determine the defining attributes, (5) identify a model case, (6) identify board line, related contrary invented and illegitimate cases, (7) identify antecedents and consequences, and (8) define empirical referents. In this analysis of workload, steps 5 and 6 were not included.

\section{Definition and uses of concept}

When defining a concept, it is imperative to identify as many possible ways in which the concept is used; this gives a comprehensive view of the concept's limitations and extensions ${ }^{2}$. To retrieve information on the concept, workload, data bases and resources such as CINAHL, Medline, Ovid, dictionaries, books and journals that correlated to the concept were used.

Workload is a compound word and when separated the oxford dictionary defines 'work' as an activity that involves mental or physical effort to achieve a goal and the word 'load' is defined as a heavy thing being carried ${ }^{4}$. Oxford Living Dictionaries $^{4}$ define workload as the amount of work that someone or something can do. The Merriam-Webster dictionary $^{5}$ defines the term workload as the amount of work to be done and incorporates the aspect of time.

In the construction industry, the term workload is viewed not only regarding the efforts applied but also considering the complexity of work $^{6}$. Ofori $^{6}$ examines the nature of the construction industry related to the concept workload to the volume of work, a variety of tasks related to the work, and the location where the job must be done. This explanation shows that a large volume of work in places considered to be complex may indicate increased workload.

In the academic field, the use of the concept becomes more complex and is dependent on who is defining the term workload. For example, instructors and professors impart knowledge to students, workload involves ensuring that they 
deliver all the information, and they assess all the students within a specified time ${ }^{7}$. For students, workload involves the materials they have to study and the related activities they must do within a specified time ${ }^{7}$. As revealed, the aspect of time is vital when defining workload in the academic sector.

In the accounting field, the concept workload is defined regarding the worklife balance. Buchheit, Dalton, Harp, and Hollingsworth $^{8}$ ascertain that accountants and auditors work long hours. For this reason, they experience exhaustion and are not able to perform other tasks efficiently. While time and fatigue are evident in the definition, the inability to engage in other important activities of life due to the stress of work is a clear demonstration of increased workload.

In law, workload is defined as the effect on the body and the mind. Samarasekara, Perera, and Narangoda ${ }^{9}$ relate increased workload among lawyers to the extended periods that they have to work, the mental stresses that comes with dealing with clients, and overall dissatisfaction due to the delays at the workplace. Therefore, in the field of law, workload can be defined as the physical and emotional efforts needed to perform a given task.

Among the mechanics, workload is not quite different from other professions. For instance, Kalantari, Arghami, Ahmadi, Garosi, and Zanjirani ${ }^{10}$ indicates that the time spent by workers in the assembly line work determines their exhaustion after work. This affirmation shows that the term workload in mechanics refers to the amount of work done at a specific time interval.
In agriculture, the term workload refers to the time spent working and the performance of all activities involved within the specified period ${ }^{11}$. Logstein ${ }^{11}$ examines farm related concerns among farmers and indicates that many farm activities performed for a long time can lead to exhaustion. Noticeably, in the agriculture field, the aspect of time is of the essence when defining workload.

In the field of religion, workload involves having many responsibilities ${ }^{12}$. Isacco, Sahker, Krinock, Sim, and Hamilton $^{12}$ explain workload in religion as a situation where religious leaders have many responsibilities and tasks to accomplish due to the limited numbers of members in religious group who can perform them. While there exists no precise definition of the concept in philosophy, the idea is similar in business and communication. Zhang, Martin, Powley, and Chen ${ }^{13}$ define workload in business as the availability of numerous duties that strain the efforts of those who must perform them. In religion it can be concluded that workload is the amount of work that is proportional to the available amount of workers.

In nursing and healthcare as a whole, workload relates to the time, work, and the available resources. For example, Alghamdi ${ }^{14}$ defines nursing workload as the ratio of demands for the available resources. The resources may be the personnel, time, money, or the materials needed to ensure the achievement of any task. Any deficit of these resources may strain the required work thus leading to the increased workload. In the nursing profession, workload is often used when referring to the nursing shortage, nursing 
fatigue, and patient demands among other factors that increase the amount of work ${ }^{15}$. Healthcare stakeholders should pay great attention to the nursing workload because of the great impact it has on patients' outcome and financial feasibility of the organization.

\section{Attributes}

Attributes are groups of characteristics that are most frequently closely linked to the concept ${ }^{2}$. Using terms correlated to nursing, three attributes were identified; time, mental state, and assignment $^{7,8, \& 11}$. As in other professions, time is of great importance in the nursing profession. Webster Dictionary ${ }^{16}$ defines time as the "point or period when something should occur." Most healthcare organizations have a time schedule for when medications should be administered, diagnostic test and procedures should be done; missing these important tasks can affect the patient outcome negatively. Mental state refers to the person's psychological state which can be evaluated when a particular event occurs or it can be evaluated over period of time ${ }^{17}$. Nursing is a very demanding and a fast paced profession that requires attention to details. Any event that affects the nurses' mental status negatively puts not only the nurse at risk for adverse event to occur, but also the patient. Normal bedside nurses are given assignments (group of patients) upon arrival to their unit. The number of patients and the level of acuity of the patients a nurse has, plays a role in the quality of care the patient receives, nursing retention and patient and staff satisfaction $^{17}$.
Workload in nursing: A concept analysis

\section{Antecedents}

Walker \& Avant $^{2}$ describe antecedents as action that must be present before workload can occur. Four actions related to nursing metaparadigm have been identified: health, environment, nursing and person (patient). According to Nikfarid et. al" "metaparadigm is a statement or group of statements identifying its importance phenomena." Health is relative to the individual and is defined according to the individual's outlook $^{19}$. Before the concept of workload in relation to nursing can occur, patients who seek healthcare services must exist. Environment is not only external but also internal and focuses on the surrounding that affects the patient ${ }^{19-20}$. The condition of the clinical environment can affect both the nurse and the patient. For the nurse, a clinical environment that does not have the resources and support can affect the nurse's workload which in turn affects patient care. Nursing is defined as the integration and expression of the arts and science and encompass the delivery of optimal health outcomes for the patient "through mutual relationship in a safe and caring environment"19-20. Person refers to the patients who receive care ${ }^{19-20}$. The amount of patients assigned to the nurse, is an integral part of the concept of workload.

\section{Consequences}

According to Walker \& Avant $^{2}$ consequences are events or incidents that occur as a result of the concept. Three events can arise after the occurrence of this concept: safety of practice, retention rate, and cost. Swiger ${ }^{15}$ associates increased nursing workload to the reduction in the 
quality of health services. Therefore, reducing nursing workload can increase safe nursing practice and improve the outcomes of patients. MacPhee et al. ${ }^{21}$ associates increased workload with job stress which can result in low retention rate. Therefore, a reduced workload can enhance job satisfaction and further improve decision-making thus enhancing nurses' productivity resulting in increased nurse retention rate. Finally, Kjellberg et al. $^{22}$ argue that reduced quality of patient care can result in increased costs of managing adverse events. In addition, recruiting and training nurses is expensive; therefore employing and retaining nurses is of paramount importance to reduce the costs associated with high turnover of bedside nurses.

Figure 1. Workload in nursing.

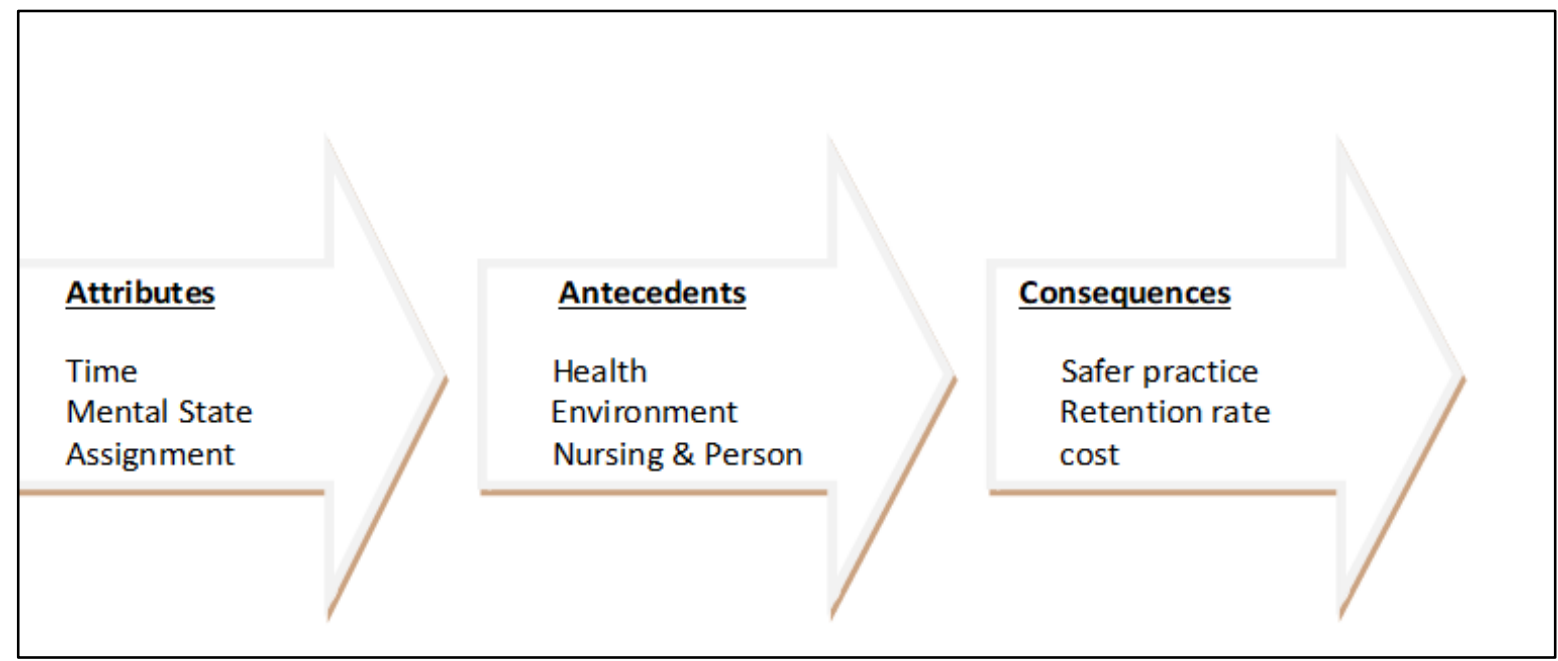

\section{Empirical Referents}

Empirical referents is described as groups or classes of actual phenomena that validate the occurrence of the concept itself $^{1-2}$. Empirical referents provide tangible methods in which to evaluate and measure the effectiveness or the lack thereof in regards to nursing workload ${ }^{1}$. Many organizations and government bodies have developed tools, policies, and pass laws to regulate nursing workload. The federal government sets the standard for how healthcare organizations should staff nurses. The forty two (42) code of Federal Regulation requires hospitals who receive Medicare to have adequate nursing staff $^{23}$. While the Regulation did not specify what adequate nursing staff is, it is upon this Federal Regulation which states and other organizations build their policies regarding nursing workload.

The American Nursing Association $^{23}$ in conjunction with Avalere designed a staffing model to improve patient outcomes. In this staffing model, the experts looked not only at the number of patients to nurse, but on the acuity of the patient, the type of unit, number of admissions, discharges, transfers, and staff skill level among other areas. They found that taking all of this into consideration will create an optimal staffing model that will positively impact patient outcome and prevent adverse effect on the nurse ${ }^{23}$. 
Indiana University developed a patient-acuity tool to promote equitable nurse-patient assignments ${ }^{24}$. The tool has five acuity categories which should be completed by the charge nurse: 1) complicated procedures, 2) education (health), 3) therapeutic interventions, 4) oral medications, and 5) and complicated I.V. drugs and other medications ${ }^{24}$. Each category has four (4) examples of care required ranging from one (1) lowest acuity and four (4) highest acuity ${ }^{24}$. The patient-acuity tool is then tallied and the scores are than translated to patient assignments based on the nurses' experience and skill $\operatorname{set}^{24}$.

\section{CONCLUSION}

The concept workload is widely used in nursing as it relates to patient-tonurse ratio and will continue to be used in practice. Analyzing the concept workload gives an insight on how nursing staff management can positively or negatively affect nurses' and patients' physical and psychological being. While the concept is widely used in the nursing profession, further studies are needed along with development of tools that will aid nursing leaders when giving patient assignments. This will allow healthcare leaders to focus on appropriate nursing staff management to increase the efficiency of service delivery in healthcare.

\section{REFERENCES}

${ }^{1}$ Perez, K. \& Cianelli. R. Critical thinking in nursing: A concept analysis. 2015. Horiz Enferm. [Internet]. 2015 [cited 2018 December 5]; 26(1): 83-87. Available

from:
Workload in nursing: A concept analysis http://horizonteenfermeria.uc.cl/images/ pdf/26-1/8_critical_thinking_12015.pdf

2.Walker, L. O., \& Avant, K. C. Strategies for theory construction in nursing. 2011. 5th rev ed. Upper Saddle River, NJ: Pearson Education

3. Online Etymology Dictionary. [Internet]. 2018 [cited 2018 November 27]; Available from: https://www.etymonline.com/word/wor kload/

4. Oxford Living Dictionaries. [Internet]. 2018 [cited 2018 November 27]; Available from: https://en.oxforddictionaries.com/definit ion/work

${ }^{5}$ Merriam-Webster. [Internet]. 2018 [cited 2018 November 27]; Available from: https://www.merriamwebster.com/dictionary/workload

6. Ofori, G. Nature of the construction industry, its needs and its development: A review of four decades of research. Journal of Construction in Developing Countries. [Internet] 2015 [cited 2018 November 27]; 20(2), 115135. Available from: http://web.usm.my/jcdc/vol20_2_2015/J CDC\%2020(2)\%202015-Art.\%207(115135).pdf

7. Hernesniemi, E., Raty, H., Kasanen, K., Cheng, X., Hong, J., \& Kuittinen, M. Perception of workload and its relation to perceived teaching and learning environments among Finnish and Chinese University Students. International Journal of Higher Education. [Internet] 2017 [cited 2018 November 27] 6(5), 42-55. Available from doi:10.5430/ijhe.v6n5p42

${ }^{8}$ Buchheit, S., Dalton, D. W., Harp, N. L., \& Hollingsworth, C. W. A contemporary 
Diaz, J., Danvers-Perez, K.

analysis of accounting professionals' work-life balance. Accounting Horizons. 2015; 30(1): 41-62.

9. Samarasekara, E. S. Y., Perera, S., \& Narangoda, B. Occupational stress and burnout among lawyers in Sri Lanka. Management Studies and Economic Systems. [Internet]. 2016 [cited 2018 August 23]; 54(3811), 1-7. Available from: http://www.msaes.org/article_14080_7e f21290546599ff60bf3f27b13ff983.pdf

10. Kalantari, R., Arghami, S., Ahmadi, E., Garosi, E., \& Zanjirani, F. A. Relationship between workload and low back pain in assembly line workers. Journal of Kermanshah University of Medical Science. [Internet]. 2016 [cited 2018 August 23]; 20(1), 26-29. Available from: https://www.researchgate.net/publicatio n/305474690_Relationship_between_w orkload_and_low_back_pain_in_assem bly_line_workers_Article_Info

11. Logstein, B. Farm-related concerns and mental health status among Norwegian farmers. Journal of Agromedicine. [Internet]. 2016 [cited 2018 August 23]; 21(4), 316-326. Available from: doi:10.1080/1059924x.2016.1211055

12.Isacco, A., Sahker, E., Krinock, E., Sim, W., \& Hamilton, D. How religious beliefs and practices influence the psychological health of Catholic priests. American Journal of Men's Health. [Internet]. 2016 [cited 2018 November 27]; 10(4), 325-337. Available from: doi: $10.1177 / 1557988314567325$

13.Zhang, M., Martin, P., Powley, W., \& Chen, J. Workload management in database management systems: A 2018, Horiz. Enferm., 28,3,204-211 taxonomy. IEEE Transactions on Knowledge and Data Engineering. [Internet]. 2018 [cited 2018 November 27]; 30(7), 1386-1402. Available from doi: 10.1109/TKDE.2017.2767044

14. Alghamdi, M. G. Nursing workload: A concept analysis. Journal of Nursing Management. [Internet]. 2016 [2018 November 25]; 24(4), 449-457. Available from doi:10.1111/jonm.12354

${ }^{15 .}$ Swiger, P. A., Vance, D. E., \& Patrician, P. A. Nursing workload in the acute-care setting: A concept analysis of nursing workload. Nursing Outlook. [Internet]. 2018 [cited 2018 December 3]; 64(3), 244-254. Available from: http://dx.doi.org/10.1016/j.outlook.2016 .01 .003

16. Merriam-Webster Dictionary. Definition of time. [Internet] 2018. [cited 2018 December 3]; Available from: https://www.merriamwebster.com/dictionary/time

${ }^{17}$ Choi J. \& Miller, P. Registered Nurse Perception of Patient Assignment Linking to Working Conditions and Outcomes. Journal of Nursing Scholarship. [Internet] 2018. [cited 2018 December 3]; 50(5):530-539. Available from: doi:10.1111/jnu.12418.

${ }^{18 .}$ Nikfarid, L., Hekmat, N., Vedad, A., \& Rajabi, A. (2018). The main nursing metaparadigm concepts in human caring theory and Persian mysticism: a comparative study. Journal of medical ethics and history of medicine. [Internet]. 2018 [cited 2018 December 5]; 11(6). Available from: https://www.ncbi.nlm.nih.gov/pmc/artic les/PMC6150916/

${ }^{19}$ Thompson, C. J. What is nursing metaparadigm? Nursing Education 
Workload in nursing: A concept analysis

Expert. [Internet]. 2017. [2018 December 5]; Available from: https://nursingeducationexpert.com/met aparadigm/

${ }^{20}$ Dupree, D. Four basic metaparadigm concepts in nursing. Career Trend. [Internet]. 2017. [2018 December 5]; Available from: https://careertrend.com/13373959/fourbasic-metaparadigm-concepts-innursing

21. MacPhee, M., Dahinten, V. S., \& Havaei, F. The impact of heavy perceived nurse workloads on patient and nurse outcomes. Administrative Sciences. [Internet] 2017. [cited 2018 November 27] 7(1), 1-17. Available from: doi:10.3390/admsci7010007

${ }^{22 .}$ Kjellberg, J., Wolf, R. T., Kruse, M., Rasmussen, S. R., Vestergaard, J.,
Nielsen, K. J., \& Rasmussen, K. Costs associated with adverse events among acute patients. BMC Health Services Research. [Internet] 2017. [cited 2018 August 29]; 17(1), 1-7. Available from: doi: 10.1186/s12913-017-2605-5

${ }^{23 .}$ American Nurses Association. Nursing staffing. [Internet] 2018. [cited 2018 December 3]; Available from: https://www.nursingworld.org/practicepolicy/advocacy/state/nurse-staffing/

24.Kidd, M., Grove, K., Kaiser, M., Swoboda, B., \& Taylor, A. A new patient-acuity tool promotes equitable nurse patient assignments. Workforce Management. [Internet] 2014. [cited 2018 December 2]; Available from: https://www.americannursetoday.com/w p-content/uploads/2014/03/ant3Workforce-Management-Acuity304.pdf 